\title{
Genetic parameters and morphometric characteristics of two generations from the GIFT strain of the Nile Tilapia
}

\section{Parâmetros genéticos e características morfométricas de duas gerações de Tilápia do Nilo linhagem GIFT}

\author{
Sheila Nogueira de Oliveira ${ }^{1 *}$; Carlos Antonio Lopes de Oliveira ${ }^{2}$; \\ Luis Alexandre Filho ${ }^{3}$; Emiko Kawakami de Resende \\ Nelson Mauricio Lopera Barrero ${ }^{5}$; Natali Miwa Kunita ${ }^{6}$; \\ Victor Francisco Araya Santander ${ }^{7}$; Ricardo Pereira Ribeiro ${ }^{8}$
}

\begin{abstract}
The objective of this work was to estimate the (co)variance and the genetic parameters for weight and average daily gain from two national generations of the GIFT strain of the Nile tilapia (Oreochromis niloticus). We evaluated 3918 fish from two generations of the breeding program from the Universidade Estadual de Maringá, Northwestern Paraná. Univariate and bivariate analysis were carried out using Bayesian inference. The estimates of heritability using one-trait models for weight was 0.15 , average daily gain was 0.19 , fish length was 0.23 , fish width was 0.19 , standard length was 0.17 , fish height was 0.15 , and the head length was 0.17 . The genetic and phenotypic correlations were above 0.68 and 0.95 , respectively. The values of Spearman and Pearson correlations for breeding values of the morphometric traits in relation to average daily gain ranged from 0.58 to 0.98 and from 0.63 to 0.99 , respectively. In the second generation (G2), the genetic gain was $2.6 \%$, the effective size of the population was 94 , and the inbreeding coefficient was 0.005 . In the next generation (G3), these values were $8.1 \%, 124$ and 0.004 , respectively. The genetic gains over the generations gradually increased from one generation to another, indicating that the criterion, average daily gain, chosen for feature selection was efficient.
\end{abstract}

Key words: Bayesian inference, breeding, fish, Oreochromis niloticus, selection

\section{Resumo}

O objetivo deste trabalho foi estimar a (co) variância e os parâmetros genéticos para peso e ganho de peso médio diário de duas gerações de tilápia do Nilo (Oreochromis niloticus) linhagem GIFT. Foram avaliados 3.918 peixes por análise univariada e bivariada, utilizando inferência Bayesiana.

${ }^{1}$ Prof $^{\mathrm{a}}$ Dr $^{\mathrm{a}}$, Dept ${ }^{\mathrm{o}}$ de Zootecnia, Universidade do Oeste do Paraná, UNIOESTE, Marechal Candido Rondon, PR, Brasil. E-mail: she uem@hotmail.com

${ }^{2}$ Prof. Dr., Dept ${ }^{\circ}$ de Zootecnia, Universidade Estadual de Maringá, UEM, Maringá, PR, Brasil. E-mail: caloliveira@uem.br

3 Prof. Dr., Dept ${ }^{\circ}$ de Zootecnia, UEM, Diamante do Norte, PR, Brasil. E-mail: lafilho@uem.br

${ }^{4} \mathrm{Dr}^{\mathrm{a}}$ Pesquisadora da Empresa Brasileira de Pesquisa Agropecuária, Embrapa Pantanal, Corumba, MS, Brasil. E-mail: emiko. resende@embrapa.br

5 Prof. Dr., Dept ${ }^{\mathrm{o}}$ de Zootecnia, Universidade Estadual de Londrina, UEL, Londrina, PR, Brasil. E-mail: nmlopera@uel.br

${ }^{6}$ Mestre, Programa de Pós-Graduação em Zootecnia, UEM, Maringá, PR, Brasil. E-mail: nat_kunita@hotmail.com

7 Prof. Dr., Ciências da Computação, Centro de Ciências Exatas e Tecnológicas, UNIOESTE, Cascavel, PR, Brasil. E-mail: victor. santander@unioeste.br

${ }^{8}$ Prof. Dr., Dept ${ }^{\circ}$ de Zootecnia, UEM, Maringá, PR, Brasil. E-mail: rpribeiro@uem.br

* Author for correspondence 
As estimativas de herdabilidade usando modelos de análise unicaracteristica para o peso foi de 0,15 e para o ganho em peso médio diário foi de 0,19 . Nas características morfométricas: comprimento total, comprimento padrão, largura, altura, tamanho da cabeça, os valores para herdabilidade foram de 0,$23 ; 0,17 ; 0,19 ; 0,15$ e 0,17 respectivamente. A correlação de Spearman e Pearson para os valores genéticos das características morfométricas em relação ao ganho de peso médio diário variaram de 0,58 a 0,98 e 0,63 a 0,99 . Na segunda geração (G2), o ganho genético foi de $2,6 \%$, o tamanho efetivo da população foi de 94 , e coeficiente de endogamia foi de 0,005 . Na geração (G3) estes valores foram de $8,1 \%, 124$ e 0,004 . As estimativas de (co) variância e parâmetros genéticos para peso e ganho de peso médio diário demonstraram que o ganho genético ao longo de gerações é gradual e crescente de uma geração para a outra indicando que o critério de seleção escolhido foi eficiente.

Palavras-chave: Inferência bayesiana, melhoramento, Oreochromis niloticus, peixe, seleção

\section{Introduction}

Currently, aquaculture in Brazil is one of the sectors that are booming, with average annual growth superior to traditional agricultural activities, such as poultry, swine and cattle production (BORGHETTI et al., 2003; FAO, 2012). Current data show that in 2010, 60 million tons of fish (an increase of $7.5 \%$ compared to the previous year) were produced worldwide, resulting in 119 billion dollars in foreign exchange. Brazil, with a production of 479.4 million tonnes of fish, is the third largest producer in the Americas, behind only the United States and Chile (FAO, 2012).

In 2002 and 2005, two varieties from international breeding programs were introduced into Brazil. First, the GST variety from the GenoMar Supreme program in Norway was introduced by the facilities of the Aquabel fish farm, and next the GIFT variety (Genetically Improved Farmed Tilapias) was introduced. This variety was developed by the ICLARM (International Center for Living Aquatic Resources Management), currently the World Fish Center in Malaysia. The GIFT strain was developed from 20 years of selection, where four wild strains of tilapia caught in 1988-1989 in Egypt, Ghana, Kenya and Senegal, and confined four strains introduced in the Philippines from 1979 to 1984 were involved, Israel, Singapore, Thailand and Taiwan (BENTSEN et al., 1998). Until 2005, Brazil had no fish-breeding program. In the absence of this infrastructure, the fish improvement was based on the phenotypes of wild lines or on massal selection. Accordingly, the potential of production was lower or similar to the animals available in the wild without the discrimination of endogamy during the mating period (PONZONI, 2006).

Fish selection allows the choice of parents to contribute genes for the next generation. The aim is to increase the frequency of genes with the effects proposed by the program (SANTOS, 2009) and to increase production (LEONHARDT et al., 2006). Faithful accuracy of (co)variance components is necessary to select the genetic parameters in an adequate and efficient way, to predict the genetic values and to obtain excellent responses from the selection program.

Until very recently, there had not been local responses from structured fish-breeding programs based on consolidate quantitative data controlling the individual pedigree and genetic evaluation by BLUP (Best Linear Unbiased Prediction) (SANTOS, 2009). Currently, breeding programs to select outstanding tilapias have been focused on the growth rate gain (PONZONI et al., 2005), although responses from individual morphometric traits can increase the level of information (PONZONI et al., 2006). Thus, alternative criteria to the total gain based on the genetic correlation between the morphometric traits and weight or average daily gain evaluated during the fish growth may increase the levels of productivity and standardise the produce from the outstanding individuals. As researchers in 
several countries have studied the genetic control of various components of meat production in tilapias (PONZONI et al., 2005; RUTTEN et al., 2005; NGUYEN et al., 2007; KHAW et al., 2008), these responses have stimulated similar investigations under the climate conditions of Brazil.

Accurate estimates of genetic parameters are of fundamental importance in fish breeding because it allows to the fish breeders to predict the genetic values and to identify the outstanding animals as a result of genetic differences from populations, environments, types of analyses and the methods of estimating the components of (co)variance. The Bayesian method, for example, has been used in fish breeding to estimate these components and the genetic parameters since 1980 (GIANOLA; FERNANDO, 1986; VAN TASSEL; VAN VLECK, 1996; LUO et al., 2001). This method allows the fish breeders to analyse large data-sets without the statistical solutions required to solve the equations of mixed models, and to accurately estimate the (co) variance components and genetic parameters of the traits of interest.

The objective of this work was to estimate the (co)variance and the genetic parameters for weight and average daily gain from two grown in Brazil of the GIFT strain of the Nile tilapia.

\section{Materials and Methods}

The Tilapia Breeding Programme in the Paraná State started in 2005 when the World Fish Center in Malaysia introduced about 600 animals from 30 fullsib families of the variety GIFT of the Nile tilapia into the Fish Research Centre of the Universidade Estadual de Maringá. These families have been maintained in various earthen ponds protected by greenhouses ever since. In this experiment, the pedigree of all of the animals from the Malaysian brood stock was identified by "Passive Integrated Transponder (PIT) tags" (Animal TAG, Korth RFID
Ltd, São Carlos). The criterion of fish selection was the average daily gain (growth rate).

Each spawned cluster was allocated to individual net cages to produce a uniform density of full-sib fry. The methodology for raising fry and fingerlings was similar to the reports of Santos et al. (2011). We considered, however, common environmental effects for fry because of the motherhood period and the common environmental effects for fingerlings. This decision was made necessary because of the period between motherhood and the tagging when the fingerlings stayed together. We tagged 2196 fish of the second generation (G2/2008 March to July) and 1722 fish of the third generation (G3/2009 June at October) when each animal weighed about $15 \mathrm{~g}$. These tagged fish were raised in cage nets measuring $2 \times 2 \times 1.7 \mathrm{~m}$ that were set up in the Corvo River in the Diamante do Norte County (22\%39'21'S and $52^{\circ} 51$ '36”'W), until they reach approximately 320 grams of body weight. The animals were divided into groups, genetically connected according to the number of tank networks used for both G2, the G3. The initial population (population G0 from the Genetic Improvement Program, State University of Maringa) was formed by endogamous couples that do not share a male to a female (animals from Malaysia), creating 32 full-sib families.

We individually assessed the progeny and selected the new parents for the mating season 2007/2008 (first generation, G1), now in the ratio of one male to two females, resulting in 33 half-sib families and full sibs. From the predicted values, the top 180 individuals used as breeders in the mating 2008/2009 season (second generation, G2) were selected, yielding 58 half-sibling families and full sibs. Just as in $\mathrm{G} 2$, formed the mating season 2009/2010, which resulted in 78 families from generation three (G3).

Analyses were performed using a data-set containing information on approximately 50 
individuals per family, half-brother and half sibs grown in 2008 (G2) and 2009 (G3), totalling 3918 animals. The relationship matrix considered the pedigree of all animals generated from specimens coming from Malaysia and contained 5600 animals within an "animal-father-mother" structure. The selection criterion used was average daily weight gain (growth rate).

Each month, we collected the fish live weight, the head length, the fish width and height, the standard fish length, and the body length measurements of 50 individuals per family and generation after the individual identification of sex and age. These data were statistically analysed by an animal model with additive genetic effects, common effects of the fry environment, common effects of the hatchery environment and the residual effects. These effects were analysed together with the fixed effects from the net cage, effects from the raising year, and effects of the fish gender. The common effects of environments were defined through one- and twotraits of two generations analysed either together or apart. We combined the data of final fish live weight and the average daily gains.

These analyses were carried out using the MTGSAM system (Multiple Trait using Gibbs Sampling Animal Models), developed by Van Tassel and Van Vleck (1995). This program allows for additive genetic effects common to the fry and fingerling environments in conjunction with the residual effect that have the normal prior distribution for one- and two-trait analyses. We considered the flat prior distribution for the effects of year, net cage, age and sex; a prior distribution for the components of (co)variance was the inverse Chi-square and Wishard for the one- and two-trait analyses, respectively.

For these analyses, Gibbs chains of 500,000 iterations were generated and the samples were taken at 15 cycle intervals after the burn-in of 50,000 iterations. Thus, the next 30,000 samples permitted us to obtain the posterior distribution of the variance components and the credibility intervals at $95 \%$ of probability during every analysis. The convergence was monitored by graphic analysis. The diagnosis tests of Heidelberg and Welch (1983), implemented in version 0.4 of the CODA library (Convergence Diagnosis and Output Analysis) by Cowles et al. (1995), was available in the $\mathrm{R}$ software (version 2.8.1). The matrix model was:

$$
\mathrm{Y}=\mathrm{X} \beta+\mathrm{Z}_{1} \mathrm{a}+\mathrm{Z}_{2} \mathrm{c}+\mathrm{Z}_{3} \mathrm{w}+\mathrm{e}
$$

In this model, $\mathrm{y}$ is the vector of observations; $\mathrm{X}$ $, Z_{1}, Z_{2}$ and $Z_{3}$ are matrices of incidence for the environmental effects, direct genetic effects and common environments for fry and fingerlings, respectively; $\beta$ is the vector of the identified environmental effects; and a, c, w and e are the vectors of additive genetic effects, common environments of fry and fingerlings, and the residual effects, respectively.

The joint distribution of ' $y, a, c, w$ ' and ' $e$ ' is:

$$
Y=\left[\begin{array}{l}
y_{1} \\
y_{2}
\end{array}\right]=\left[\begin{array}{cc}
X_{1} & 0 \\
0 & X_{2}
\end{array}\right]\left[\begin{array}{l}
\beta_{1} \\
\beta_{2}
\end{array}\right]+\left[\begin{array}{cc}
Z_{1_{1}} & 0 \\
0 & Z_{1_{2}}
\end{array}\right]\left[\begin{array}{l}
a_{1} \\
a_{2}
\end{array}\right]+\left[\begin{array}{cc}
Z_{2_{1}} & 0 \\
0 & Z_{22}
\end{array}\right]\left[\begin{array}{l}
c_{1} \\
c_{2}
\end{array}\right]+\left[\begin{array}{cc}
Z_{3_{1}} & 0 \\
0 & Z_{3_{2}}
\end{array}\right]\left[\begin{array}{l}
w_{1} \\
w_{2}
\end{array}\right]+\left[\begin{array}{l}
e_{1} \\
e_{2}
\end{array}\right]
$$

where $\mathrm{Y}_{1}$ and $\mathrm{Y}_{2}$ are the vector observations of live weight, and the indices 1 and 2 indicate the generation being analysed.

The joint distribution of ' $\mathrm{y}, \mathrm{a}, \mathrm{c}, \mathrm{w}$ ' and ' $\mathrm{e}$ ' is:

$$
\left[\begin{array}{c}
y \\
a \\
c \\
w \\
e
\end{array}\right] \sim N M V\left[\begin{array}{c}
X \beta \\
0 \\
0 \\
0 \\
0
\end{array}\right] ;\left[\begin{array}{ccccc}
V & Z_{1} G & Z_{2} G & Z_{3} G & I_{n} \sigma_{e}{ }^{2} \\
G Z_{1}{ }^{\prime} & G & \emptyset & \emptyset & \emptyset \\
C Z_{2}{ }^{\prime} & \emptyset & C & \emptyset & \emptyset \\
W Z_{3} & \emptyset & \emptyset & W & \emptyset \\
I_{n} \sigma_{e}{ }^{2} & \emptyset & \emptyset & \emptyset & I_{n} \sigma_{e}{ }^{2}
\end{array}\right]
$$


In this matrix, $\mathrm{V}=\mathrm{Z}_{1} \mathrm{GZ}_{1}{ }^{\prime}+\mathrm{Z}_{2} \mathrm{CZ}_{2}{ }^{\prime}+\mathrm{Z}_{3} \mathrm{WZ}_{3}{ }^{\prime}+\mathrm{R}$

Are for the bi-traits analysis:

$$
\mathrm{G}=\mathrm{G}_{*} \otimes \mathrm{A} ;
$$

where $\mathrm{A}$ is the relationship matrix; $\otimes$ is the Kronecker product; and $\mathrm{G}$ is the matrix of additive genetic (co)variance:

$$
\begin{aligned}
& G_{*}=\left[\begin{array}{cc}
\sigma_{a_{1}}^{2} & \sigma_{a_{1} a_{2}} \\
\sigma_{a_{2} a_{1}} & \sigma_{a_{2}}^{2}
\end{array}\right] \\
& \mathrm{C}=\mathrm{I}_{1} \otimes \mathrm{C}_{*}
\end{aligned}
$$

In this matrix, $I_{1}$ represents the identity matrix with rank equal to the number of full-sib families, and $\mathrm{C}_{*}$ is the (co)variance matrix of the common effect of fry and environment as follows:

$$
C_{*}=\left[\begin{array}{cc}
\sigma_{c_{1}}^{2} & \sigma_{c_{1} c_{2}} \\
\sigma_{c_{2} c_{1}} & \sigma_{c_{2}}^{2}
\end{array}\right]
$$

Next, we have

$$
\mathrm{W}=\mathrm{I}_{1} \otimes \mathrm{W}_{*}
$$

where $I_{m}$ represents the identity matrix. The rank is equal to the number of containers in the fingerling environment used every year. $\mathrm{W}_{*}$ is the matrix of (co)variance of the common effect in the fingerling environment:

$$
W_{*}=\left[\begin{array}{cc}
\sigma_{w_{1}}^{2} & \sigma_{w_{1} w_{2}} \\
\sigma_{w_{2} w_{1}} & \sigma_{w_{2}}^{2}
\end{array}\right]
$$

and

$$
\mathrm{R}=\mathrm{I}_{\mathrm{m}} \otimes \mathrm{R}_{*}
$$

where $\mathrm{I}_{\mathrm{m}}$ represents the identity matrix, the rank is equal to the fish number, of containers in the used every year. $\mathrm{R}$ is the matrix of (co)variance of the residual effect.

$$
R_{*}=\left[\begin{array}{cc}
\sigma_{e_{1}}^{2} & \sigma_{e_{1} e_{2}} \\
\sigma_{e_{2} e_{1}} & \sigma_{e_{2}}^{2}
\end{array}\right]
$$

The genetic gain was calculated by:

$$
\Delta \mathrm{G}=\mathrm{i} \sqrt{\mathrm{b}^{\prime} \mathrm{Pb}}
$$

In this equation, $\mathrm{b}=$ vector, predictor $\mathrm{P}=$ matrix of phenotypic (co)variances, and $\mathrm{i}=$ selective intensity with:

$$
i=\frac{S}{\sigma_{p}}
$$

In this ratio, $\mathrm{S}=$ differential of selection, which is calculated by:

$$
(\bar{Y} s-\bar{Y} p) \text {. }
$$

In this equation, $\bar{Y}_{\mathrm{S}}$ is the mean from the selected fish, and $\bar{Y} p$ is the mean from the population.

Also, $\sigma_{p}=$ phenotypic standard deviation.

$$
\begin{aligned}
\Delta G & =\frac{S}{\sigma_{p}} \cdot \sigma_{p} b \\
\Delta G & =S \cdot b \\
\Delta G & =(\bar{Y} s-\bar{Y} p) \cdot b \\
\Delta G & =\bar{a} s-\bar{a} p .
\end{aligned}
$$

The percentage of genetic gain relative to the average of the population is:

$$
\Delta G=\frac{\bar{a} s-\bar{a} p(g / \text { dia })}{\bar{x} p\left({ }^{g} /{ }_{\text {dia }}\right)} .100
$$

We used the expression defined by Wright (1931) to determine the effective size of the population in which:

$$
\frac{1}{N e}=\frac{1}{4 N m}+\frac{1}{4 N f}
$$

In this equation, $\mathrm{Ne}=$ effective size of the population; $\mathrm{Nm}=$ number of male parents; and $\mathrm{Nf}=$ number of female parents. The inbreeding coefficient was obtained by MTGSAM software. Thereafter, we calculated the restricted heritability, and the genetic and phenotypic correlations between the traits. We estimate the Spearman correlations using the predicted genetic values in the two-trait analysis to monitor the different fish ranking when the height, width, total body length, standard body length, head and weight were modified. The Pearson and Spearman correlations were estimated from the 
predicted genetic values in the two-trait analyses using data of both generations.

\section{Results and Discussion}

The estimates of heritability varied from 0.15 for fish weight (W) to 0.23 for total length (TL) (Table 1). The average daily gain (ADG) participation in the heritable genetic differences had an average magnitude. Differences between the posterior averages for the morphometric traits were not verified in the interval estimates because the credibility intervals were similar. The estimates of heritability using one-trait analysis were similar to the means reported by Khaw et al. (2009) for fish weight evaluated under different farming conditions, but these current estimates were lower than the responses reported by Ponzoni et al. (2005). These values of 0.15 and 0.23 were similar to the estimates reported from experiments using REML analyses (RUTTEN et al., 2005; CHARO-KARISA et al., 2005; MALUWA et al., 2006). Furthermore, the estimates of 0.23 for fish length and 0.17 for fish height were similar to the figures of 0.26 and 0.17 reported by Nguyen et al. (2007).

Table 1. Genetic parameters of the weight (W, grams), average daily gain (ADG, grams), total fish length (TL, $\mathrm{cm}$ ), standard length $(\mathrm{SL}, \mathrm{cm})$, fish height $(\mathrm{FH}, \mathrm{cm})$, fish width $(\mathrm{FW}, \mathrm{cm})$ and head length $(\mathrm{HL}, \mathrm{cm})$ using data from two generations of Nile tilapia, with their credibility intervals (obtained by the R software, CODA library) in brackets.

\begin{tabular}{lcccc}
\hline \multicolumn{1}{c}{ Traits } & $\sigma^{2} \mathrm{p}$ & $\mathrm{h}^{2}$ & $\mathrm{c}^{2}$ & $\mathrm{~W}^{2}$ \\
\hline $\mathrm{W}$ & 8220.85 & 0.15 & 0.03 & 0.07 \\
& $(7679-8935)$ & $(0.06-0.31)$ & $(0.01-0.04)$ & $(0.03-0.11)$ \\
ADG & 0.1879 & 0.19 & 0.026 & 0.11 \\
& $(0.17-0.21)$ & $(0.067-0.38)$ & $(0.013-0.044)$ & $(0.062-0.18)$ \\
$\mathrm{TL}$ & 4.068 & 0.23 & 0.023 & 0.05 \\
& $(3.75-4.53)$ & $(0.09-0.43)$ & $(0.011-0.04)$ & $(0.02-0.11)$ \\
$\mathrm{SL}$ & 2.772 & 0.19 & 0.025 & 0.07 \\
& $(2.57-3.04)$ & $(0.07-0.38)$ & $(0.01-0.04)$ & $(0.03-0.12)$ \\
$\mathrm{FH}$ & 0.6097 & 0.17 & 0.024 & 0.06 \\
& $(0.56-0.66)$ & $(0.07-0.33)$ & $(0.01-0.04)$ & $(0.03-0.12)$ \\
FW & 0.1223 & 0.15 & 0.02 & 0.05 \\
& $(0.11-0.13)$ & $(0.07-0.29)$ & $(0.01-0.03)$ & $(0.03-0.10)$ \\
$\mathrm{HL}$ & 0.3089 & 0.17 & 0.02 & 0.07 \\
& $(0.28-0.33)$ & $(0.07-0.33)$ & $(0.01-0.04)$ & $(0.03-0.12)$ \\
\hline
\end{tabular}

$\sigma^{2} \mathrm{p}=$ phenotypic variance; $\mathrm{h}^{2}=$ heritability; $\mathrm{c}^{2}=$ fry common environment; $\mathrm{w}^{2}=$ fingerling common environment.

When the estimate of heritability is high, the emphasis in the selection happens at the individual level, i.e. the best individuals are chosen to compose the breeding stock. However, when the estimates for $\mathrm{h}^{2}$ have from medium to low values, as verified in this current work, the selection of the best families is of greater importance. Individual selection provides faster responses in genetic gain / generation, but it has the disadvantage of reducing the variability in less time than the selection within families.

We did not observe any differences in the heritability values in single-trait analysis and bi-characteristics, demonstrating that the unifeature is sufficient to explain the behaviour of the characteristics (W, ADG, TL, SL, FH, FW, HL). However, the two-trait analysis helped in the 
identification of the correlations between these traits. Charo-Karisa et al. (2007) found estimates for FH, FW and SL of $0.60,0.73$ and 0.62 , respectively. These values were higher than those found in the current study. However, the animals in the CharoKarisa et al. (2007) study were evaluated in growing conditions that were different from the current conditions. Results similar to the present study were reported by Reis Neto (2012).

The common environment for the fry $\left(c^{2}\right)$ had less relative importance in comparison to the total variation than the common environment $\left(\mathrm{w}^{2}\right)$ of the fingerlings. These estimates ranged from 0.02 to 0.03 for $\mathrm{c}^{2}$ and from 0.05 to 0.11 for $\mathrm{w}^{2}$, and no differences in point estimates (posterior average) for $\mathrm{c}^{2}$ were detected. The $\mathrm{w}^{2}$ value of the posterior mean for ADG had twice the relative importance of variation in total $\mathrm{FW}$ and TL features. For $\mathrm{w}^{2}$, the posterior mean for ADG was two times higher than the relative importance in comparison with the total variation estimated for TL and FW, but the credibility intervals of these means were all similar. Although the magnitude of $\mathrm{c}^{2}$ and $\mathrm{w}^{2}$ were low, these factors have to be maintained in the models because there is no zero in the credibility intervals, which means a small probability of null values for both components.

Although the estimates of $\mathrm{c}^{2}$ and $\mathrm{w}^{2}$ for fish weight were lower than those reported by Ponzoni et al. (2005) who found a relative participation of 0.15 in the total variation for the common maternal environment, we considered the common effects from fry and fingerling production. In addition, the current results were similar to the estimates of Khaw et al. (2009) who calculated a figure of 0.15 (spawning season) using a one-trait analysis. The explanation for these responses rests with the similarities between the common effects of fry and fingerling environments and the spawning season (PONZONI et al., 2005; KHAW et al., 2009). Nguyen et al. (2010) reported values for the effect of the common environment for morphometric measurements of tilapia from $4 \%$ to $5 \%$ of the total variation, unlike Ponzoni et al. (2005) who found the range to be from $15 \%$ to $26 \%$.

The relative participation in weight of fry common environment and fingerling common environment of $0.10\left(c^{2}=0.03+w^{2}=0.07\right.$ (Table 1)) in the model structure are similar to data in the literature where Charo-Karisa et al. (2005) reported 0.11 after using the REML methodology. These responses strengthen the importance of both factors (common environment of fry and fingerlings in the model structure). Thus, the environmental influence on fish responses from the selection processes is better understood. The credibility interval of $95 \%$ corroborates the high reliability in the posterior estimates for these morphometric traits. The highest value from the one-trait analysis was 0.23 obtained for total fish length (0.09-0.43) and the lowest was 0.15 (0.070.29 ) for weight and fish width, respectively. The explanation for these responses may be the use of different populations in subtropical regions, the current tropical environment and a production system that uses net cages instead of the earthen ponds.

The phenotype correlations ranged from 0.76 between head length and fish width to 0.97 between total length and standard length (Table 2). These results demonstrate that weight and ADG are strongly associated, and that the gains generated in one characteristic are also obtained in the other. Furthermore, the selection criterion (ADG) can be replaced by the characteristic weight without affecting the breeding program. 
Table 2. Genetic correlations (below the diagonal line), phenotypic correlations (above the diagonal line) and the average heritability for the morphometric characteristics and performance.

\begin{tabular}{lccccccc}
\hline \multicolumn{1}{c}{ Traits } & $\mathrm{W}$ & ADG & TL & SL & FH & FW & HL \\
\hline \multirow{2}{*}{$\mathrm{W}$} & 0.17 & 0.95 & 0.92 & 0.91 & 0.89 & 0.85 & 0.85 \\
& & $(0.94-0.95)$ & $(0.90-0.93)$ & $(0.90-0.93)$ & $(0.88-0.90)$ & $(0.83-0.86)$ & $(0.83-0.87)$ \\
\hline \multirow{2}{*}{ ADG } & 0.89 & \multirow{2}{*}{0.15} & 0.90 & 0.89 & 0.86 & 0.83 & 0.83 \\
& $(0.78-0.95)$ & & $(0.88-0.91)$ & $(0.88-0.90)$ & $(0.85-0.88)$ & $(0.81-0.84)$ & $(0.86-0.88)$ \\
\hline \multirow{2}{*}{ TL } & 0.84 & 0.90 & 0.23 & 0.97 & 0.87 & 0.80 & 0.87 \\
& $(0.73-0.97)$ & $(0.74-0.97)$ & & $(0.96-0.97)$ & $(0.86-0.89)$ & $(0.78-0.82)$ & $(0.86-0.88)$ \\
\hline \multirow{2}{*}{$\mathrm{SL}$} & 0.90 & 0.87 & 0.97 & 0.19 & 0.87 & 0.77 & 0.86 \\
& $(0.73-097)$ & $(0.70-0.95)$ & $(0.92-0.99)$ & & $(0.85-0.88)$ & $(0.77-0.82)$ & $(0.85-0.87)$ \\
\hline \multirow{2}{*}{ FH } & 0.91 & 0.86 & 0.86 & 0.86 & 0.16 & 0.80 & 0.84 \\
& $(0.77-0.97)$ & $(0.66-0.95)$ & $(0.64-0.94)$ & $(0.62-0.95)$ & & $(0.78-0.82)$ & $(0.82-0.85)$ \\
\hline \multirow{2}{*}{ FW } & 0.88 & 0.88 & 0.73 & 0.70 & 0.75 & 0.17 & 0.76 \\
& $(0.72-0.93)$ & $(0.62-0.95)$ & $(0.44-0.90)$ & $(0.41-0.88)$ & $(0.51-0.89)$ & $0.73-0.78)$ \\
\hline \multirow{2}{*}{$\mathrm{HL}$} & 0.85 & 0.82 & 0.92 & 0.90 & 0.84 & 0.68 & 0.16 \\
& $(0.63-0.95)$ & $(0.63-0.95)$ & $(0.79-0.97)$ & $(0.73-0.97)$ & $(0.61-0.95)$ & $(0.38-0.87)$ & 0.16 \\
\hline
\end{tabular}

$\mathrm{W}=$ weight (grams), $\mathrm{ADG}=$ average daily gain $($ grams), $\mathrm{TL}=$ total length $(\mathrm{cm}), \mathrm{SL}=$ standard length $(\mathrm{cm}), \mathrm{FH}=$ fish height $(\mathrm{cm})$, $\mathrm{FW}=$ fish width $(\mathrm{cm})$ and $\mathrm{HL}=$ head length $(\mathrm{cm})$.

The highest genetic correlation of 0.97 was calculated between total fish length and the standard length. This result, from similar measures (TL and SL), demonstrates through a high correlation that only one measure can be adopted: the TL or SL. Unlike the lowest genetic correlation of 0.68 that was calculated between fish width and head length, the values indicate that while the gain increases the width decreases the gain length of the head. The fish width had a genetic correlation lower than 0.8 when associated with TL, SL, FH and HL, and higher than 0.85 when associated with $\mathrm{W}$ and ADG.

Charo-Karisa et al. (2007) also found high genetic correlations between morphometric characteristics of tilapia. They concluded that it was unnecessary to use all these features in a program of genetic improvement, unlike the work of Nguyen et al. (2010), who also worked with tilapia and found lower values of genetic correlations. These responses suggest that the characteristics change during the animal growth. The explanation may be the difference in the growth of the body parts as the weight of the animals (SANTOS et al., 2006).

The higher the weight gain and ADG, the greater is the width of the fish. This is an important result because the width of the fish is related to the size of the fillet. Strong associations between weight, ADG and the morphometric measurements were observed.

When the GPD was used as a selection criterion, strong genetic and phenotypic associations with this morphometric measure, with values ranging from 0.82 to 0.90 and from 0.83 to 0.95 , respectively, were observed (Table 2). These estimates suggest that the selection criteria by using the ADG allow the fish to have also gains in the morphometric characteristics. These morphometric characteristics can also be used as selection criteria in breeding programs of tilapia reaching the same result of higher production (weight and average daily gain). The high correlation between weight and fish length is similar to previous reports of tilapias (RUTTEN et al., 2005; NGUYEN et al., 2007).

The ranking and the magnitude of these correlations were independent of the applied selection because the correlations between the ADG and the morphometric traits were high (above 0.80), either for the rank (Spearman) or the magnitude, 
which had positive signals (Pearson).

The two-trait analysis allowed us to find the correlation between the genetic and phenotypic characteristics (W and ADG) with the morphometric characteristics, and all the values for these correlations were above 0.68 (Table 2). These results indicate the close relationship between the characteristics, which allow responses to selection of a feature, even when this selection is made in another characteristic. The results were similar to those estimated by Nguyen et al. (2007).

In terms of fish selection using the different traits, we observed variation in the rank correlations
(Table 3). Estimates of the Spearman correlation indicate a small modification in the rank for the average daily gain and fish weight when both traits were the criteria of selection. Both the genetic and phenotypic correlations were considered high, i.e. above 0.7 , except for the correlation $\mathrm{x}$ head width, which was 0.68 .

This shows that there may be a correlated response between feature selection target (GPD) and the other characteristics studied, since, for all correlation analyses, the parameter daily weight gain remained high (above 0.8) for both order (Spearman) as to its magnitude and direction of response - positive (Pearson).

Table 3. Spearman coefficients of correlation (above the diagonal line) and Pearson coefficients of correlation (below the diagonal line) for performance characteristics (W and $\mathrm{ADG}$ ) and morphometric characteristics.

\begin{tabular}{lccccccc}
\hline \multicolumn{1}{c}{ Traits } & W & ADG & TL & SL & FH & FW & HL \\
\hline W & - & 0.94 & 0.85 & 0.87 & 0.90 & 0.85 & 0.76 \\
ADG & 0.95 & - & 0.85 & 0.86 & 0.58 & 0.83 & 0.78 \\
TL & 0.88 & 0.88 & - & 0.98 & 0.86 & 0.66 & 0.94 \\
SL & 0.90 & 0.89 & 0.99 & - & 0.86 & 0.62 & 0.92 \\
FH & 0.92 & 0.63 & 0.89 & 0.86 & - & 0.77 & 0.86 \\
FW & 0.88 & 0.86 & 0.72 & 0.66 & 0.80 & - & 0.58 \\
HL & 0.81 & 0.81 & 0.95 & 0.93 & 0.86 & 0.63 & - \\
\hline
\end{tabular}

$\mathrm{W}=$ weight $($ grams $), \mathrm{ADG}=$ average daily gain $($ grams $), \mathrm{TL}=$ total length $(\mathrm{cm}), \mathrm{SL}=$ standard length $(\mathrm{cm}), \mathrm{FH}=\mathrm{Fish}$ height $(\mathrm{cm})$, $\mathrm{FW}=$ fish width $(\mathrm{cm}), \mathrm{HL}=$ head length $(\mathrm{cm})$.

The average daily gain was highly correlated to the fish weight. The Pearson coefficient of correlation ranged from 0.63 to 0.89 . In contrast, the average daily gain had the lowest correlation with the fish height, which is in agreement with the estimates from the rank correlations.

The process of fish selection can affect the structure of the population. The reduction in the number of parents increases the possibility of mating related animals and this fact reduces genetic variability. The current estimates of genetic gains indicate increases in the selection responses through the generations. The genetic gain in the third generation was higher than that in the second generation. The effective number (Ne: effective number of the population: the number of animals leaving progeny) increased from 94 to 124 , and the inbreeding coefficient reduced from 0.005 to 0.004 (Table 4). 
Table 4. Percentage of genetic gain $(\Delta \mathrm{G})$ for ADG, effective number of the population $(\mathrm{Ne})$, the coefficient of endogamy $(\Delta \mathrm{F})$ and the number of fish per generation (obtained by univariate analysis).

\begin{tabular}{lcccc}
\hline Generations & $\Delta \mathrm{G}(\%)$ & $\mathrm{Ne}$ & $\Delta \mathrm{F}(\%)$ & Fish \\
\hline $\mathrm{G} 2$ & 2.6 & 94 & 0.005 & 2196 \\
$\mathrm{G} 3$ & 8.1 & 124 & 0.004 & 1730 \\
\hline
\end{tabular}

The genetic gain increased from G2 (0.041) to G3 (0.115), which represents gains of $2.6 \%$ in G2 and $8.1 \%$ in G3, and suggests efficacy in the fish selection without losses in the genetic variability or increases in the inbreeding levels. However, the gain of 5.5\% per generation can be considered low in comparison with reports found in the literature. Working with GIFT tilapia, Gjedrem (2000) reported the expected values of $10 \%$ and $20 \%$, while a gain of $40 \%$ in three generations was reported by Gall and Bakar (2002). One of the justifications for this gain being low may be because was have kept the best representatives of each family during animal selection, even when the genetic value of the animals showed that particular family is low, seeking to maintain the genetic variability of generation to generation.

Small populations induce inbreeding and genetic drifting, and both hinder the sustainability of breeding programs over long periods. Currently, the effective number $(\mathrm{Ne})$ of parents was able to maintain the low levels of inbreeding, which decreased from 0.005 in G2 to 0.004 in G3. The effective number of 94 individuals in the $\mathrm{G} 2$ generation is above the level of 50 fish. Meuwissen (2007) recommended at least 50 individuals, and Ponzoni et al. (2010) recommended that the population size must be maintained at levels that permit a sustainable breeding program with low inbreeding levels under a wide genetic perspective, and adapted population to new raising conditions such as environmental changes, reproduction, or both.

In conclusion, genetic gains over generations gradually increase from one generation to another, indicating that the chosen feature selection criterion (ADG) is efficient. The GIFT strain of Nile Tilapia can be used in breeding programs because they have the potential for more improvements in further generations without significant losses in the genetic variability. The estimates of the genetic parameters using information from two generations (G1 and G2) demonstrate that the selection is performed by giving emphasis to selection within families because of the low values of the estimated heritability. Even though the effects of $\mathrm{c}^{2}$ and $\mathrm{w}^{2}$ were small, it is important to keep these parameters in the model to obtain more accurate estimates of the genetic parameters.

\section{Acknowledgements}

The authors thank the Universidade Estadual de Maringá, the research group Peixegen and the $\mathrm{CNPq}$ for supporting the facilities and funding this research.

\section{References}

BENTSEN, H. B.; EKNATH, A. E.; VERA, M. S. P.; DANTING, J. C.; BOLIVAR, H. L.; REYES, R. A.; DIONISIO, E. E.; LONGALONG, F. M.; CIRCA, A. V.; TAYAMEN, M. M.; GJERD, B. Genetic improvement of farmed tilapias: growth performance in a complete diallel cross experiment with eight strains of Oreochromis niloticus. Aquaculture, Amsterdam, v. 160, n. 1-2, p. $145-$ 173, 1998.

CHARO-KARISA, H.; BOVENHUIS, H.; REZK, M. A.; PONZONI, R. W.; ARENDONK, J. A. M. Phenotypic and genetic parameters for body measurements, reproductive traits and gut length of Nile tilapia (Oreochromis niloticus) selected for growth in low-input earthen ponds. Aquaculture, Amsterdam, v. 273, n. 1, p. 15-23, 2007.

CHARO-KARISA, H.; RESKZK, M. A.; BEVENHUIS, H.; KOMEN, H. Heritability of cold tolerance in Nile tilapia, Oreochromis niloticus juveniles. Aquaculture, Amsterdam, v. 249, n. 1-4, p. 115-129, 2005. 
COWLES, K.; BEST, N.; VINES, K. Convergence diagnosis and output analysis. Cambridge: MRC Biostatistics Unit, UK, 1995. Version 0.40. 41 p.

FAO - FOOD AND AGRICULTURE ORGANIZATION OF THE UNITED NATIONS. The state of world fisheries and aquaculture, 2012. Roma: FAO, 2012. 209 p.

GALL, G. A. E.; BAKAR, Y. Application of mixed-model techniques to fish breed improvement: analysis of breedingvalues selection to increase 98-day body weight in tilapia. Aquaculture, Amsterdam, v. 212, n. 1-4, p. 98-113, 2002.

GIANOLA, D.; FERNANDO, R. L. Bayesian methods in animal breeding theory. Journal of Animal Science, Champaign, v. 63, n. 1, p. 217-244, 1986.

GJEDREM, T. Genetic improvement of cold-water species. Aquaculture, Amsterdam, v. 31, n. 1, p. 25-33, 2000.

HEIDELBERG, P.; WELCH, P. D. Simulation run length control in the presence of an initial transient. Operations Research, Hanover, v. 31, n. 6, p. 1109-1114, 1983.

KHAW, H. L.; BOVENHUIS, H.; PONZONI, R. W.; REZK, M. A.; CHARO-KARISA, H.; KOMEN, H. Genetic analysis of Nile Tilapia (Oreochromis niloticus) selection line reared in two input environments. Aquaculture, Amsterdam, v. 294, n. 1-2, p. 37-42, 2009.

KHAW, H. L.; PONZONI, R. W.; DANTING, M. J. C.; Estimation of genetic change in the GIFT strain of Nile Tilapia (Oreochromis niloticus) by comparing contemporary progeny produced by males born in 1991 or in 2003 . Aquaculture, Amsterdam, v. 275, n. 1-4, p. 64-69, 2008.

LEONHARDT, C. M. R.; CAETANO, L. G.; FENOCCHIO, A.; CAETANO FILHO, M.; LEONHARDT, J. H. Caracterização cariotípica de um estoque de tilápia do Nilo, Oreochromis niloticus, da Universidade Estadual de Londrina, mediante diversas técnicas de bandamento cromossômico. Semina Ciências Agrárias, Londrina, v. 27, n. 4, p. 679-684, 2006.

LUO, M. F.; BOETTCHER P. J.; SCHAEFFER L. R.; DEKKERS, J. C. M. bayesian inference for categorical traits with an application to variance component estimation. Journal of Dairy Science, Champaign, v. 84, n. 3, p. 694-704, 2001.

MALUWA, A. O.; GJERDE, B.; PONZONI, R. W. Genetic parameters and genotype by environment interaction for body weight of Oreochromis shiranus. Aquaculture, Amsterdam, v. 259, n. 1-4, p. 47-55, 2006.

MEUWISSEN, T. H. E. Operation of conservation schemes. In: OLDENBROEK, K. (Ed.). Utilization and conservation of farm animal genetic resources. Wageningen: Academic Press Publishers, 2007. p. 167194.
NGUYEN, H. N.; KHAW, H. L.; PONZONI, R. W.; HAMZAH, A.; TAN, S.; KAMARUZZANMAN, N. Can sexual dimorphism and body shape be altered in Nile Tilapia (Oreochromis niloticus) by genetic means? Aquaculture, Amsterdam, v. 272, n. 1, p. 38-46, 2007.

NGUYEN, H. N.; PONZONI, R. W.; ABU-BAKAR, K. R.; HAMZAH, A.; KHAW, H. L.; YEE, H. Y. Correlated response in fillet weight and yield to selection for increased harvest weight in genetically improved farmed tilapia (GIFT strain), Oreochromis niloticus. Aquaculture, Amsterdam, v. 305, n. 1, p. 1-5, 2010.

PONZONI, R. W. Genetic improvement and effective dissemination: keys to prosperous and sustainable aquaculture industries. In: PONZONI, R. W.; ACOSTA, B. O.; PONNIAN, A. G. (Ed.). Development of aquatic animal genetic improvement and dissemination programs: current status an action plans. Bayan Lepos: The Word Fish Center, 2006. p. 1-6.

PONZONI, R. W.; HAMZAH, A.; TAN, S.; KAMARUZZAMAN, N. Genetic parameters an response to selection for live weight in the GIFT strain of Nile Tilapia (Oreochromis niloticus). Aquaculture, Amsterdam, v. 247, n. 1-4, p. 203-210, 2005.

PONZONI, R. W.; KHAW, H. L.; ABU BAKAR, K. R.; HAMZAH, A.; KAMARUZZAMAN, N.; NGUYEN, N. H. A Comparison of GIFT and Red Tilapia for fillet yield and flesh quality assessed by a panel of untrained consumers. In: WORLD CONGRESS ON GENETICS APPLIED TO LIVESTOCK PRODUCTION, 8., 2006, Belo Horizonte. Anais... Belo Horizonte: ASAS, 2006. p. 1-4.

PONZONI, R. W.; KHAW, H. L.; NGUYEN, H. N.; HAMZAH, A. Inbreeding and effective population size in the Malaysian nucleus of the GIFT strain of Nile tilapia (Oreochromis niloticus). Aquaculture, Amsterdam, v. 302, n. 1-2, p. 42-48, 2010.

REIS NETO, R. V. Avaliação genética das características morfométricas de tilápias do Nilo variedade GIFT sob seleção para ganho em peso. 2012. Tese (Doutorado em Zootecnia), Programa de Pós-Graduação em Zootecnia, Universidade Federal de Lavras, Lavras.

RUTTEN, M. J. M.; KOMEN, H.; BOVENHUIS, H. Longitudinal genetic analysis of Nile tilapia (Oreochromis niloticus L.) body weight using a random regression model. Aquaculture, Amsterdam, v. 246, n. 1-4, p. 101-113, 2005.

SANTOS, A. I. Interação genótipo-ambiente $e$ estimativas de parâmetros genéticos em tilápias (Oreochromis niloticus) 2009. Tese (Doutorado em Zootecnia) - Programa de Pós-Graduação em Ciência Animal, Universidade Estadual de Maringá, Maringá. 
SANTOS, A. I.; RIBEIRO, R. P.; VARGAS, L.; MORA, F.; ALEXANDRE FILHO, L.; FORNARI, D. C.; OLIVEIRA, S. N. Bayesian genetic parameters for body weight and survival of Nile tilapia farmed in Brazil. Pesquisa Agropecuária Brasileira, Brasília, v. 46, n. 1, p. 33-43, 2011.

SANTOS, V. B.; FREATO, T. A.; FREITAS, R. T.; LOGATO, P. V. R. Relative growth and allometric coefficients of body components of strains of Nile Tilapia (Oreochromis niloticus). Ciência Animal Brasileira, Goiania, v. 7, n. 4, p. 357-364, 2006.
VAN TASSEL, C. P.; VAN VLECK, L. D. A manual for use of MTGSAM. A set of FORTRAN programs to apply Gibbs sampling to animal models for variance components estimation (DRAFT). Lincoln: Department of Agriculture, Agricultural Research Service, 1995. 86 p.

Multiple-trait gibbs sampler for animal models: flexible programs for Bayesian and likelihood-based (co)variance components inference. Journal of Animal Science, Champaign, v. 74, n. 11, p. 2586-2597, 1996.

WRIGHT, S. Evolution in mendelian populations. Genetics, Bethesda, v. 16, n. 2, p. 97-159, 1931. 